\title{
HIV and contraceptive use in Zimbabwe amongst sexually active adolescent girls and women: Secondary analysis of Zimbabwe Demographic Health survey data
}

\section{Godfrey Musuka ( $\nabla$ gm2660@cumc.columbia.edu )}

Columbia University Medical Center: Columbia University Irving Medical Center https://orcid.org/00000001-9077-4429

\section{Zindoga Mukandavire}

Coventry University

\section{Grant Murewanhema}

University of Zimbabwe Faculty of Medicine: University of Zimbabwe College of Health Sciences Innocent Chingombe

Columbia University Medical Center: Columbia University Irving Medical Center

\section{Diego F Cuadros}

University of Cincinnati

\section{Farirai Mutenherwa}

BRTI: Biomedical Research and Training Institute

\section{Tafadzwa Dzinamarira}

Columbia University Medical Center: Columbia University Irving Medical Center

\section{Rouzeh Eghtessadi}

\section{SAfAIDS}

\section{Noble Malunguza}

NUST: National University of Sciences and Technology

\section{Munyaradzi Mapingure}

Columbia University Medical Center: Columbia University Irving Medical Center

\section{Research Article}

Keywords: HIV, Zimbabwe, contraceptive

Posted Date: March 10th, 2021

DOI: https://doi.org/10.21203/rs.3.rs-314068/v1 
License: (c) (i) This work is licensed under a Creative Commons Attribution 4.0 International License. Read Full License 


\section{Abstract}

Objective To describe contraceptive usage amongst HIV positive and negative sexually active adolescent girls and women using data from the Zimbabwe Demographic and Health Survey (2015-16). Methods We used statistical analysis to determine the association between use of various methods of contraception and HIV status using the Zimbabwe Demographic and Health Survey, 2015-16 data. Results: Sexually active adolescent girls and women on the pill and on injections were less likely to be HIV positive compared to those not using any method of contraception, odds ratio (95\% confidence interval) 0.54 (0.45-0.64), $p=0.001$ and $0.75(0.59-0.96), p=0.020$ respectively. Those using either a male or female condom were more likely to be HIV positive, OR $(95 \% \mathrm{Cl}) 3.36$ (2.63-4.28), $p=0.001$. Conclusions: This study corroborates that the use of implants and intrauterine contraceptive devices is very low both among the HIV-positive and HIV-negative sexually active adolescent girls and women, with no statistically significant differences between the two groups. However, statistically significant differences were noted in the use of condoms ( $13 \%$ versus $3 \%, p=0.001)$, with those who are HIV positive having a higher usage of condoms compared to those who are HIV negative. This may reflect that HIV positive individuals have received appropriate counselling messages on the need to protect their sexual partners.

\section{Background}

HIV continues to be a major public health challenge in Zimbabwe with a national prevalence of $14 \%$, one of the highest globally and $11.8 \%$ for the $15-49$ age group [1]. Owing to several socioeconomic and cultural disadvantages, adolescent girls and women and are differentially affected by the HIV epidemic and constitute an estimated 67 percent of people living with HIV/AIDS (PLWHA) in the country. The country has a comprehensive family planning (FP) strategy which has seen a gradual increase in the uptake of modern methods of contraception over the past two decades [2]. However, evidence of integration of HIV education and family planning and maternal health services is generally lacking in the region including Zimbabwe [3-5]. This is despite the fact that integration of family planning and HIV education has been shown to be effective in preventing both HIV and unplanned pregnancies. In the region, family planning and HIV visits are the only contacts women have with the health system and an opportunity to educate them on the prevention of both is lost [3]. Resultantly, higher incidence of unintended pregnancies in women living with the virus than in the general population have been reported [6].

The Zimbabwe National Family Planning Council (ZNFPC) [7] lists the following family planning methods in use: (a) Short-Acting Methods (emergency contraception, the pill, male and female condoms and injectables, fertility awareness based methods, and lactational amenorrhea method), (b) Long Acting Reversible Contraceptives (Implants and Intrauterine Contraceptive Device) and Permanent Methods (both male and female surgical contraception). Between 1988 and 2015, use of modern contraception among women increased from 36 percent to 66 percent [8]. Hormonal contraceptives, in particular oral contraceptives, implants and injectables dominate the method mix [2]. However, unlike condoms, hormonal contraceptives do not offer dual protection. Understanding the pattern of FP use among 
women living with HIV is critical for formulating relevant public health interventions to improve uptake and use of reliable methods in this population to reduce the incidence of unintended pregnancies. Our study uses Zimbabwe Demographic and Health Survey (ZDHS) 2015 data to describe the various contraceptive methods used by HIV positive and negative women in Zimbabwe.

\section{Methods}

\section{Study area and data sources}

The ZDHS methodology has been described elsewhere. Briefly, subjects were enrolled in the ZDHS via a two-stage sampling procedure to select households. A total of 400 ZDHS sample locations were selected. The study population was limited to 7397 sexually active adolescent girls and women 15 to 49 years who had ever had sex, were asked about contraceptive usage and had a definitive HIV result.

Anonymous HIV testing was performed with the informed consent of all sampled individuals.

HIV serostatus was determined by testing with the enzyme-linked immunosorbent assay (ELISA) Vironostika Uniform $2 \mathrm{Ag} / \mathrm{AB}$. All samples that tested positive and a random sample of $10 \%$ of samples that tested negative were retested with a second ELISA, the Enzygnost ${ }^{\circledR}$ HIV Integral II assay (Siemens). Positive samples on both tests were classified as HIV positive. If the first and second tests were discordant, the two ELISAs were repeated; if the results remained discordant, a confirmatory test, the HIV 2.2 western blot (DiaSorin), was administered.

\section{Statistical analysis}

STATA Version 16.1, Texas USA, was used to conduct statistical analysis. We used simple proportion to describe the characteristics of the women included in the analysis. We presented a table showing various types of contraceptive used by HIV positive and negative women. Thereafter, for each contraceptive method, women not using any contraceptive method at all was used as the comparison group to show association between contraceptive use and HIV status. Odds ratios and their $95 \%$ confidence intervals were used to calculate the risk estimate for HIV positivity among these women for various forms of contraceptives used. Statistical significance cut-off for purposes of describing the significant contraceptive factors associated with HIV positivity was set at $\mathrm{p}<0.05$.

\section{Results}

From Table 1, approximately two thirds (4248) of the participants lived in rural areas, consistent with the national population distribution by area of residence, and (4696) had secondary education. The majority of the women 5170 (72\%) were married. The largest (43\%) religious group was the apostolic sect with 2958 respondents.

Table 1: Participant demographic characteristics 


\begin{tabular}{|c|c|}
\hline Variable & $\begin{array}{r}\text { Female Frequency n (\%) } \\
\mathbf{N}=7397\end{array}$ \\
\hline $\begin{array}{l}\text { Age group in years } \\
15-19 \\
20-24 \\
25-29 \\
30-34 \\
35-39 \\
40-44 \\
45-49\end{array}$ & $\begin{array}{r}655(9) \\
1385(18) \\
1466(20) \\
1426(20) \\
1074(15) \\
873(12) \\
518(7)\end{array}$ \\
\hline $\begin{array}{l}\text { Type of residence } \\
\text { Urban } \\
\text { Rural } \\
\end{array}$ & $\begin{array}{l}3149(37) \\
4248(63) \\
\end{array}$ \\
\hline $\begin{array}{l}\text { Highest education level } \\
\text { None } \\
\text { Primary } \\
\text { Secondary } \\
\text { Higher } \\
\end{array}$ & $\begin{array}{r}94(2) \\
2002(28) \\
4696(63) \\
605(7) \\
\end{array}$ \\
\hline $\begin{array}{l}\text { Marital status } \\
\text { Never in union } \\
\text { Married } \\
\text { Living with partner } \\
\text { Widowed } \\
\text { Divorced } \\
\text { Separated } \\
\end{array}$ & $\begin{array}{r}780(8) \\
5170(72) \\
285(4) \\
388(5) \\
444(6) \\
330(4) \\
\end{array}$ \\
\hline $\begin{array}{l}\text { Religion } \\
\text { Traditional } \\
\text { Roman catholic } \\
\text { Protestant } \\
\text { Pentecostal } \\
\text { Apostolic sect } \\
\text { Other Christian } \\
\text { Muslim } \\
\text { None } \\
\text { Other } \\
\end{array}$ & $\begin{array}{r}44(1) \\
464(6) \\
1108(15) \\
1937(25) \\
2958(43) \\
456(5) \\
21(0) \\
401(6) \\
8(0)\end{array}$ \\
\hline
\end{tabular}

Figure 1 below shows the geospatial distribution of contraceptive usage by women in Zimbabwe. The maps show that the use of oral contraceptives and injectable contraception is low in high HIV prevalence areas.

From Table 2, a smaller proportion of the HIV positive people (23\%) uses the pill compared to their HIV negative counterparts $(37 \%), p<0.001$. Usage of IUD was very low for both groups and not significantly different. There was no significant differences in proportions of injection use by for the HIV positive and the HIV negative. A significantly larger proportion of the HIV positive (13\%) uses condoms compared to the HIV negative (35), $P<0.001$. There is low adoption of the female and male sterilisation methods and the usage is not different between the HIV positive and the HIV negative. Very small proportions use the withdrawal method and there are no significant differences between the two groups of HIV statuses. Only $11 \%$ of the HIV positive women uses implants compared to $10 \%$ of the HIV negative and these proportions are statistically the same. A negligible proportion of the women from both groups use the LAM method

Table 2: Type of contraceptive use by HIV status of the women 


\begin{tabular}{|c|c|c|c|}
\hline Contraceptive type & $\begin{array}{l}\text { HIV Positive } \\
\text { n (\%) }\end{array}$ & $\begin{array}{l}\text { HIV Negative } \\
\text { n (\%) }\end{array}$ & P-Value \\
\hline $\begin{array}{l}\text { Pill } \\
\text { Not using pill } \\
\text { Using }\end{array}$ & $\begin{array}{r}1216(77) \\
315(23) \\
\end{array}$ & $\begin{array}{l}3768(63) \\
2098(37) \\
\end{array}$ & 0.001 \\
\hline $\begin{array}{l}\text { IUD } \\
\text { Not using IUD } \\
\text { Using } \\
\end{array}$ & $\begin{array}{r}1521(99) \\
10(1) \\
\end{array}$ & $\begin{array}{r}5834(100) \\
32(0) \\
\end{array}$ & 0.554 \\
\hline $\begin{array}{l}\text { Injections } \\
\text { Not using injections } \\
\text { Using }\end{array}$ & $\begin{array}{r}1399(92) \\
132(8) \\
\end{array}$ & $\begin{array}{r}5293(91) \\
573(9) \\
\end{array}$ & 0.147 \\
\hline $\begin{array}{l}\text { Male or female condom } \\
\text { Not using condom } \\
\text { Using }\end{array}$ & $\begin{array}{r}1333(87) \\
198(13)\end{array}$ & $\begin{array}{r}5629(97) \\
237(3)\end{array}$ & 0.001 \\
\hline $\begin{array}{l}\text { Male or female sterilization } \\
\text { Not using sterilization } \\
\text { Using }\end{array}$ & $\begin{array}{r}1518(99) \\
13(1)\end{array}$ & $\begin{array}{r}5814(99) \\
52(1)\end{array}$ & 0.992 \\
\hline $\begin{array}{l}\text { Withdrawal } \\
\text { Not using withdrawal } \\
\text { Using }\end{array}$ & $\begin{array}{r}1524(99) \\
7(1) \\
\end{array}$ & $\begin{array}{r}5833(99) \\
33(1) \\
\end{array}$ & 0.975 \\
\hline $\begin{array}{l}\text { Implants } \\
\text { Not using implants } \\
\text { Using }\end{array}$ & $\begin{array}{r}1348(89) \\
183(11)\end{array}$ & $\begin{array}{r}5266(90) \\
600(10)\end{array}$ & 0.145 \\
\hline $\begin{array}{l}\text { LAM } \\
\text { Not using LAM } \\
\text { Using }\end{array}$ & $\begin{array}{r}1528(100) \\
3(0)\end{array}$ & $\begin{array}{r}5854(100) \\
12(0)\end{array}$ & 0.840 \\
\hline
\end{tabular}

Table 3 shows the association between contraceptive use and HIV positivity. Each method is only compared to those not using any method, to eliminate background confounding. From Table 3, women on the pill and on injections were less likely to be HIV positive compared to those not using any method of contraception, odds ratio (95\% confidence interval) $0.54(0.45-0.64), p=0.001$ and $0.75(0.59-0.96)$, $p=0.024$ respectively. On the contrary, odds of being HIV positive were higher for those using either a male or female condom compared to those not using any method of contraceptive, OR $(95 \% \mathrm{Cl}) 3.37$ (2.64-4.32), $p=0.001$, indicating that they were most likely trying to protect their sexual partners.

Table 3: Association between contraceptive usage and HIV status 


\begin{tabular}{|c|c|c|c|c|}
\hline Contraceptive type & HIV Positive & HIV Negative & OR (95\% CI) & P-Value \\
\hline $\begin{array}{l}\text { Pill } \\
\text { Not using any method } \\
\text { Using }\end{array}$ & $\begin{array}{l}669(22) \\
315(13)\end{array}$ & $\begin{array}{l}2216(78) \\
2098(87)\end{array}$ & $0.54(0.45-0.64)$ & 0.001 \\
\hline $\begin{array}{l}\text { IUD } \\
\text { Not using any method } \\
\text { Using }\end{array}$ & $\begin{array}{r}669(22) \\
10(24) \\
\end{array}$ & $\begin{array}{r}2216(78) \\
32(76) \\
\end{array}$ & $1.13(0.49-2.61)$ & 0.772 \\
\hline $\begin{array}{l}\text { Injections } \\
\text { Not using any method } \\
\text { Using }\end{array}$ & $\begin{array}{l}669(22) \\
132(17) \\
\end{array}$ & $\begin{array}{r}2216(78) \\
573(83) \\
\end{array}$ & $0.75(0.59-0.96)$ & 0.024 \\
\hline $\begin{array}{l}\text { Male or female condom } \\
\text { Not using any method } \\
\text { Using }\end{array}$ & $\begin{array}{l}669(22) \\
198(49)\end{array}$ & $\begin{array}{r}2216(78) \\
237(51)\end{array}$ & $3.37(2.64-4.32)$ & 0.001 \\
\hline $\begin{array}{l}\text { Male or female sterilization } \\
\text { Not using any method } \\
\text { Using }\end{array}$ & $\begin{array}{r}669(22) \\
13(20)\end{array}$ & $\begin{array}{r}2216(78) \\
52(80)\end{array}$ & $0.89(0.44-1.79)$ & 0.734 \\
\hline $\begin{array}{l}\text { Withdrawal } \\
\text { Not using any method } \\
\text { Using }\end{array}$ & $\begin{array}{r}669 \text { (22) } \\
7(20)\end{array}$ & $\begin{array}{r}2216(78) \\
33(80)\end{array}$ & $0.90(0.35-2.30)$ & 0.818 \\
\hline $\begin{array}{l}\text { Implants } \\
\text { Not using any method } \\
\text { Using }\end{array}$ & $\begin{array}{l}669(22) \\
183(22) \\
\end{array}$ & $\begin{array}{r}2216(78) \\
600(78) \\
\end{array}$ & $1.01(0.81-1.26)$ & 0.913 \\
\hline $\begin{array}{l}\text { LAM } \\
\text { Not using any method } \\
\text { Using }\end{array}$ & $\begin{array}{r}669(22) \\
3(18) \\
\end{array}$ & $\begin{array}{r}2216(78) \\
12(82)\end{array}$ & $0.77(0.20-2.96)$ & 0.702 \\
\hline
\end{tabular}

\section{Discussion}

The trajectory of the HIV epidemic has changed significantly over the past 2 decades globally with increased life expectancy among PLWHA [9]. Widespread access to safe and effective antiretrovirals [10] has enabled women to live full reproductive lives, and children who were born with HIV are reaching adolescence and adulthood. As people become healthier, the desire for sexual activities naturally increases [11]. It is critical to ensure that women living with HIV and AIDS are enabled to enjoy their adulthood fully, and against this background, ensure safer sexual practices with regards to acquiring other sexually transmitted infections, cross-infection with other HIV strains and prevention of unintended pregnancies. A key element of sustainable development number 3 is ensuring equitable access of reproductive health services across all populations [12]. Dual protection encompasses the use of protective barrier methods concurrently with another effective method of contraception and this should be the target for the cohort of women living with HIV/AIDS.

In this cross-sectional study we analysed the mix of methods used by sexually active women living with HIV/AIDS and compared the use to their HIV-negative counterparts. Overall, the contraceptive prevalence in this study was $60 \%$. Though there are differences in the definition of contraceptive prevalence used by the ZNFPC, which reports contraceptive prevalence for married or in-union women only [2], and what we used in our study, where we included all sexually active women regardless of their marital/union status, the contraceptive prevalence rates are still comparable. The ZNFPC and UNFPA reported the prevalence of contraceptive use to be about $67 \%$ [13]. Our study population, randomly selected from the ZHDS for this study, was therefore representative of the population of Zimbabwean women. However, there is still a 
considerable unmet need in our study population and the general population of reproductive age Zimbabwean women, and public health stakeholders in family planning must devise strategies to continually improve contraceptive uptake and use.

The combined oral contraceptive pill has traditionally dominated the method mix in Zimbabwe [2]. Unfortunately, for the HIV positive woman, this may not be the best choice because of interaction with some antiretroviral medicines. Nevirapine and efavirenz, which were previously integral components of most antiretroviral regimens, which have hepatic metabolism, have been known to possibly reduce the efficacy of hormonal contraceptives [14]. Fortunately, there is currently a general switch to dolutegravircontaining regimens, which has no documented interactions with hormonal contraception. Progestin-only pills, which are commonly used by breastfeeding women, also interact significantly with anti-retrovirals and other medicines such as anti-tuberculous medicines. HIV/TB coinfection is significant in Zimbabwe [15], with a consequent risk of unintended pregnancies among women on ARVs, anti-TB medicines and some hormonal contraceptive method.

The discrepancy in the use of oral contraceptives was not accompanied by a rise in the use of the other methods such as the injectables, implants and intrauterine contraceptive devices. The use of long-acting reversible methods of contraception (LARC) was low in this study, and this is comparable to results from other studies. In one study, the use of LARC was reported by only $5.3 \%$ of women, and women who used LARC or an injectable were likely to be aged 18-29 years, and much lower in older age groups [16]. In that study, the high prevalence of unintended pregnancies, and the low use of LARC necessitated the need for strengthening integration of family planning and contraceptive awareness among women living with HIV. Innovative interventions are needed to realise maximum benefit from integration of HIV care and treatment services with family planning services [17], and must be an ongoing process.

Statistically significant differences were noted in the use of condoms, with a higher prevalence of use among the HIV-infected women ( $13 \%$ versus $3 \%, p=0.001)$. Whilst it's encouraging that those who have a positive HIV status have higher usage of condoms, which may reflect knowledge of HIV status, receipt of appropriate counselling messages or protecting their partners, the use of barrier methods is still very low in both groups. More needs to be done to promote the use of barrier methods, which are not only contraceptive, but also significantly reduce the risk of acquiring other sexually transmitted infections such as Neisseria gonorrhoeae, Chlamydia trachomatis and Human Papilloma Virus, all of which are quite prevalent in the population. Health education and health promotion messages aimed at improving the uptake of barrier methods are critical as public health aims at reducing the occurrence of new HIV infections to zero, but also to protect against other STIs which substantially increase the risk of other problems such as subfertility and cervical cancer.

This study corroborates that the use of implants and intrauterine contraceptive devices is very low both among the HIV-positive and HIV-negative women, with no statistically significant differences. These are tier 1 methods, highly protective against pregnancy and their protective efficacy is not user dependent. However, several factors serve as barriers against their uptake, including lack of knowledge, limited 
availability in resource-limited settings, and lack of appropriately trained and skilled manpower to administer these methods $[18,19]$. Several fears, myths and misconceptions surround reduced uptake of long-acting reversible contraception (LARC), including fears of disappearing IUDs, weight changes, altered bleeding patterns and subfertility [20]. Though these studies were carried out among non-HIV positive populations, there are no reasons to believe that the same barriers do not apply to the HIV-positive cohorts. Unfortunately, these are the more reliable methods for women living with HIV. The copper IUCDs have no known interactions with antiretrovirals and other medicines commonly prescribed to this cohort of women.

Examining associations between contraceptive usage and HIV status revealed statistically significant differences in the use of oral contraceptive pills, with higher use among HIV negative women (OR 0.54, $95 \% \mathrm{Cl} 0.45-0.64 . \mathrm{p}=0.001)$. There were also statistically significant differences in the use of condoms as highlighted earlier, with more HIV-positive women using condoms (OR 3.37, 95\% Cl 2.64-4.32, p = 0.001). Reasons for this difference need to be explored further to tailor-make public health interventions to promote dual contraception in the HIV-positive cohort, but also to reduce risky sexual behaviour in the HIV-negative cohort. Because this was a cross-sectional study, we cannot explain the differences, but indepth qualitative studies would be useful for identifying the possible explanations to address them appropriately.

\section{Conclusion}

Continued efforts at integration of HIV Care and Treatment services and family planning services are critical for improving contraceptive uptake among HIV positive women, to reduce the risk of unintended pregnancies and new sexually transmitted infections. A lot of work needs to be done to address the barriers and improve the uptake of long acting methods, and continued use of barrier methods. Public health players, policy makers and women living with HIV must consistently work together to attain the common goal of improving and maintaining contraceptive uptake. Safeguards must be put in place to ensure that HIV-positive women freely access this critical service and fully enjoy their sexual and reproductive health rights without discrimination.

\section{Study Limitations}

The main limitation of this study is that the ZHDS was a cross-sectional survey and collected only one biomarker, the HIV status. Therefore, some associations cannot be stated with certainty, and further studies are needed. More in-depth qualitative studies are also required to understand the barriers and facilitators of contraceptive uptake among both HIV positive and negative women. Nevertheless, the study findings significantly contribute towards understanding the patterns of contraceptive use in Zimbabwe among HIV-positive women, an area that needs continuous appraisal and tailored interventions.

\section{Abbreviations}


AIDS Acquired Immune Deficiency Syndrome

ART Antiretroviral Therapy

ARV Antiretroviral Drug

$\mathrm{COC} \quad$ Combined Oral Contraceptive

DMPA Depo medroxyprogesterone acetate

ELISA Enzyme-Linked Immunosorbent Assay

FP Family Planning

HIV Human immunodeficiency virus

IUCD Intrauterine contraceptive device

IUD Intrauterine Device

LAM Lactational Amenorrhea Method

LARCs Long-Acting Reversible Contraceptives

NET-EN Norethisterone Enathate

OR Odds Ratio

PLWHA People Living with HIV and AIDS

SAfAIDS Southern Africa AIDS Dissemination Service

STI Sexually transmitted Infection

ZDHS Zimbabwe Demographic health Survey

TB Tuberculosis

UNFPA United Nations Population Fund

ZNFPC Zimbabwe National Family Council

\section{Declarations}

\section{Ethics approval and consent to participate}

Procedures and questionnaires for standard Demographic Health Surveys (DHS) have been reviewed and approved by the ICF International Institutional Review Board (IRB). Additionally, country-specific DHS 
survey protocols are reviewed by the ICF IRB and typically by an IRB in the host country. The ICF International IRB ensures that the survey complies with the U.S. Department of Health and Human Services regulations for the protection of human subjects, while the host country IRB ensures that the survey complies with laws and norms of the nation. In the original primary data collection for each DHS, informed consent was sought from all participants prior to serological testing for HIV (http://dhsprogram.com/What-We-Do/Protecting-the-Privacy-of-DHS-SurveyRespondents.cfm\#sthash.Ot3N7n5m.dpuf). We sought and were granted permission to use the core dataset for this analysis by MEASURE DHS.

Informed consent was sought in writing. For minors, consent was obtained from their parents or guardians.

\section{Consent to publish}

Not applicable.

\section{Availability of data and materials}

The data that support the findings of this study are available from the Demographic and Health Surveys (http://www.measuredhs.com) but restrictions apply to the availability of these data, which were used under license for the current study, and so are not publicly available.

\section{Competing interests}

Drs Godfrey Musuka and Zindoga Mukandavire are Editorial Board members of BMC Public Health. All other authors declare that they have no competing interests.

\section{Funding}

N/A

\section{Authors' contributions}

GM, MM, IC, FM conceived the study. GM \& MM carried out the statistical analysis. GM wrote the first draft of the paper. All authors contributed to the writing of the manuscript. All authors read and approved the final manuscript.

\section{Acknowledgements}

Authors would like to thank all respondents for their willingness to participate in the ZDHS study and for ICF Macro for making the data available.

\section{References}


1. Ministry of Health and Child Care (MoHCC). Zimbabwe Population-based HIV Impact Assessment (ZIMPHIA 2020): Final Report. Harare. 2021.

2. ZIMBABWE. NATIONAL FAMILY PLANNING STRATEGY (ZNFPS)http://www.znfpc.org.zw/wpcontent/uploads/2019/05/ZFPS-Final.pdf.

3. Malunguza NJ, Hove-Musekwa SD, Mukandavire Z. Assessing the Potential Impact of HormonalBased Contraceptives on HIV Transmission Dynamics Among Heterosexuals. Bull Math Biol. 2017;79(4):738-71.

4. Ralph LJ, McCoy SI, Shiu K, Padian NS. Hormonal contraceptive use and women's risk of HIV acquisition: a meta-analysis of observational studies. The Lancet infectious diseases.

2015;15(2):181-9.

5. Prata N, Sreenivas A, Bellows B. Potential of dual-use policies to meet family planning and HIV prevention needs: a case study of Zimbabwe and Mozambique. BMJ Sexual Reproductive Health. 2008;34(4):219-26.

6. Wilcher R, Petruney T, Reynolds H, Cates W. From effectiveness to impact: contraception as an HIV prevention intervention. Sex Transm Infect. 2008;84(Suppl 2):ii54-60.

7. Methods of family Planning. Available from http://www.znfpc.org.zw/methods-of-family-planning/ Accessed 8 March 2021.

8. WHO issues statements on use of reversible hormonal contraception. Available from https://www.who.int/reproductivehealth/topics/family_planning/statements-reversible-hc/en/ Accessed 8 March 2021.

9. Katz IT, Maughan-Brown B. Improved life expectancy of people living with HIV: who is left behind? The lancet HIV. 2017;4(8):e324-6.

10. Ford N, Calmy A, Mills EJ. The first decade of antiretroviral therapy in Africa. Globalization health. 2011;7(1):1-6.

11. Erhabor O, Adias T, Akani C. Reproductive Health Challenges of Living with HIV-Infection in Sub Saharan Africa. Current Perspectives in HIV Infection 2013:325.

12. General Assembly. Sustainable development goals. SDGs Transform Our World. 2015.

13. In the midst of the COVID-19 pandemic UNFPA and partners call for greater efforts to ensure access to contraceptives for women and girlshttps://zimbabwe.unfpa.org/en/news/midst-covid-19pandemic-unfpa-and-partners-call-greater-efforts-ensure-access-contraceptives.

14. Womack JA, Novick G, Goulet JL. Hormonal contraceptive use in HIV-infected women using antiretroviral therapy: a systematic review. Open access journal of contraception. 2015;6:37.

15. Martino RJ, Chirenda J, Mujuru HA, Ye W, Yang Z. Characteristics Indicative of Tuberculosis/HIV Coinfection in a High-Burden Setting: Lessons from 13,802 Incident Tuberculosis Cases in Harare, Zimbabwe. The American Journal of Tropical Medicine Hygiene. 2020;103(1):214-20.

16. Sutton MY, Zhou W, Frazier EL. Unplanned pregnancies and contraceptive use among HIV-positive women in care. PloS one. 2018;13(5):e0197216. 
17. Adeniyi OV, Ajayi Al, Moyaki MG, Ter Goon D, Avramovic G, Lambert J. High rate of unplanned pregnancy in the context of integrated family planning and HIV care services in South Africa. BMC Health Serv Res. 2018;18(1):1-8.

18. Tibaijuka L, Odongo R, Welikhe E, Mukisa W, Kugonza L, Busingye I, Nabukalu P, Ngonzi J, Asiimwe SB, Bajunirwe F. Factors influencing use of long-acting versus short-acting contraceptive methods among reproductive-age women in a resource-limited setting. BMC Womens Health. 2017;17(1):113.

19. Joshi R, Khadilkar S, Patel M. Global trends in use of long-acting reversible and permanent methods of contraception: seeking a balance. International Journal of Gynecology Obstetrics. 2015;131:60-3.

20. Politi MC, Estlund A, Milne A, Buckel CM, Peipert JF, Madden T. Barriers and facilitators to implementing a patient-centered model of contraceptive provision in community health centers. Contraception reproductive medicine. 2016;1(1):1-9.

\section{Figures}
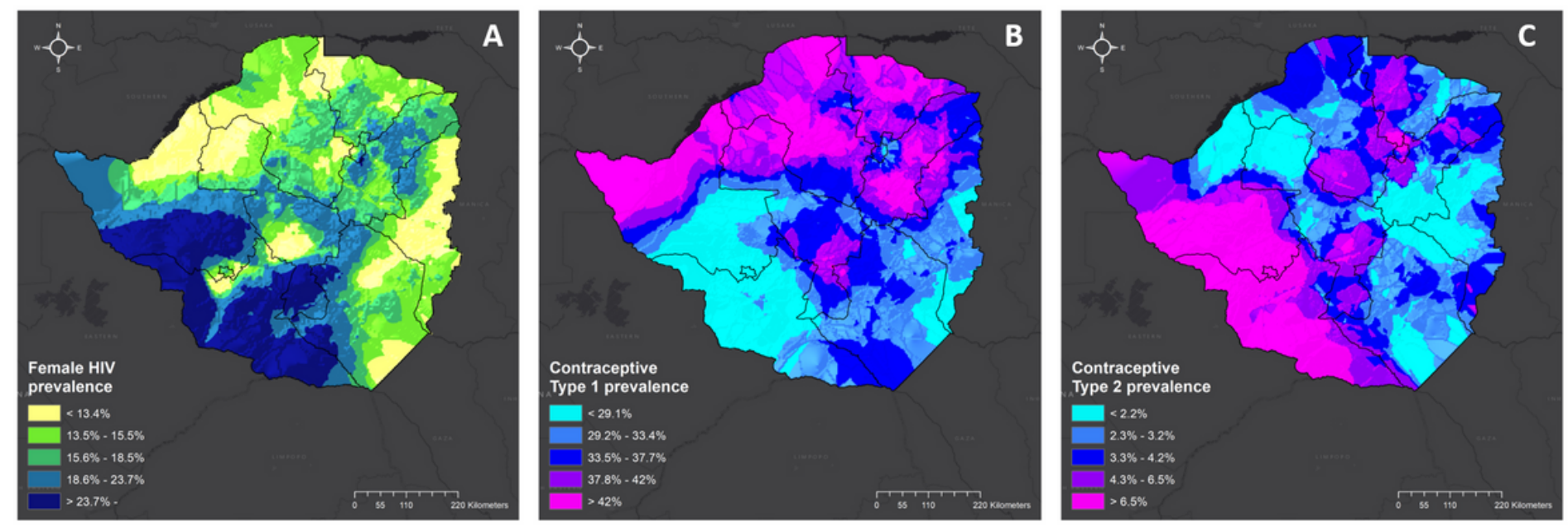

\section{Figure 1}

Shows the geospatial distribution of contraceptive usage by women in Zimbabwe. 